\section{El lenguaje teológico en los místicos: éxtasis y kénosis*}

\author{
Edith GonZÁLEZ BernaL*
}

RECIBIDO: 12-06-16. APROBADO: 12-08-16

\begin{abstract}
RESUMEN: En el presente artículo se busca enfatizar en el lenguaje teológico que los místicos utilizan para comunicar la experiencia de Dios. Ellos coinciden en que, para hablar de Dios, se tiene que acudir a analogías, y aun así las palabras no logran decir lo que realmente han vivido. En su mayoría, los místicos relatan visiones en las que Dios se les ha manifestado para darles conocimiento y claridad sobre la manera como deben orientar sus vidas y mover a otros hacia la conversión; también hacen una teología kenótica como el mejor camino para seguir a Jesús; esto es asumir la obediencia como aniquilación o desasimiento de la voluntad humana para dar paso a la voluntad divina.
\end{abstract}

Palabras Clave: Lenguaje, éxtasis, visiones, kénosis, aniquilamiento, desasimiento.
The Theological Language in the
Mystics: Ecstasy and Kenosis

Aвstract: The present article aims to stress on the theological language used by mystics to communicate their experience of God. Mystics agree on the need to use analogies in order to speak about Godeven if words are not able to express what they really have experienced. Most of them describe visions in which God reveals himself to offer them knowledge and clarity about how they should conduct their lives and move others toward conversión; they also elaborate a kinotic Theology as the best way to follow Jesus; that is, assuming obedience as annihilation or detachment of the human will in order to give way to the divine will.

KeY words: Language, Ecstasy, Visions, Kenosis, Annihilation, Detachment.

PARA CITAR ESTE ARTÍ́CULO:

González Bernal, Edith. "El lenguaje teológico en los místicos: éxtasis y kénosis". Theologica Xaveriana 182 (2016): 371-393. http://dx.doi.org/10.11144/javeriana.tx66-182.ltmek

\footnotetext{
* Artículo de reflexión derivado del proyecto de investigación "Mística medieval. El lenguaje teológico de ayer y de hoy", realizada en la Facultad de Teología, Pontificia Universidad Javeriana.

** Doctora en Teología y Doctora en Ciencias de la Educación. Profesora Asociada, Departamento de Teología de la Pontificia Universidad Javeriana. ORCID.org/0000-0003-4971-9262. Correo electrónico: edith.gonzalez@javeriana.edu.co
} 


\section{El lenguaje teológico}

La preocupación de los místicos ha sido la de comunicar lo que han padecido, visto y oído. Las quejas frecuentes vienen dadas porque, para ellos, Dios de por sí es incomprensible, inimaginable e incomunicable. De ahí que apelen a un leguaje cuyos recursos son las imágenes de la naturaleza, los sonidos, las voces, las visiones y la poesía, para hacer analogías e intentar decir una palabra sobre el misterio. Su experiencia rebasa el silencio, porque -en las visiones y percepciones que tienen- Dios les ordena poner por escrito lo que han visto y oído.

En la historia de la teología mística se encuentra un lenguaje en el que la palabra del místico es solo una aproximación mediante atributos de lo que ellos han experimentado de Dios: “...se advierte una tensión insuperable entre revelación y misterio, cognoscibilidad e incomprensibilidad, afirmación y negación, lenguaje e inefabilidad, transcendencia e inmanencia, fe y razón"'.

Michel De Certeau describe la configuración del lenguaje teológico de los místicos de los siglos XIII y XVII como un lenguaje en el que el cuerpo, los sentidos, los sentimientos y el intelecto juegan un papel fundamental:

La literatura es la prueba, en el lenguaje, del ambiguo paso de la presencia a la ausencia; atestigua una lenta transformación de la escena religiosa en escena amorosa, de la fe en erótica, cuenta como un cuerpo marcado por el deseo y grabado, herido, escrito por el otro, reemplaza la palabra reveladora e instructiva. Así luchan los místicos con el duelo, ese ángel nocturno. Pero la propedéutica medieval de una asimilación de la verdad se convierte en ellos en un cuerpo a cuerpo. $^{2}$

Searle, por su parte, reconoce que si bien los místicos ponen el cuerpo es escena para comunicar, se encuentran con las limitaciones del lenguaje:

Pero, incluso en casos donde es imposible de hecho decir exactamente lo que quiero decir, es imposible en principio llegar a ser capaz de decir exactamente lo que quiero decir. [...]. Puedo, al menos en principio, enriquecer el lenguaje introduciendo en él nuevos términos u otros recursos. ${ }^{3}$

Los místicos aseguran que son testigos de lo que relatan y asumen que lo que dicen es la verdad, porque les viene de una seguridad que precisamente no es de ellos. Así, el místico se ve en la obligación de comunicar su experiencia en responsabilidad con el misterio, como afirma Ladrière:

\footnotetext{
${ }^{1}$ Vide, Los lenguajes de Dios. Pragmática, lingüistica y teología, 21-22.

${ }^{2}$ De Certeau, La fábula mistica, 14.

${ }^{3}$ Searle, Actos de habla, 29.
} 
Quien habla como testigo ha reconocido en los acontecimientos que narra la venida del Reino de Dios, porque ha respondido positivamente a la cuestión que plantea, ha creído en la palabra de Jesús y la ha acogido en su espíritu y en su corazón como hijo de Dios y salvador. ${ }^{4}$

Lo que el místico hace es recrear su experiencia de Dios, exteriorizar un saber por medio de sentimientos y afectos que Macquarrie denomina "estados de la mente"; en ellos están la fe, la gracia, el reconocimiento de la creaturalidad, el sentimiento de lo sagrado, la reverencia y la adoración. Así,

...el lenguaje teológico está relacionado también con aquellos estados o modos afectivos que constituyen junto con las intuiciones sensibles esa apertura a la existencia que es una característica fundamental del hombre considerado como un-yo-en-el-mundo que se revela a sí mismo. ${ }^{5}$

Los místicos afirman que la experiencia de Dios es plenitud de vida cristiana, es gracia que Dios otorga a la persona para conducirla hacia él y hacerle experimentar la unión ${ }^{6}$. De esta manera, todo cristiano puede hablar de una experiencia de Dios, pues Dios se está dando en la vida cotidiana para que lo podamos conocer y llegar a dar cuenta de ello.

Las experiencias en la vida diaria son las que constituyen la base de toda otra experiencia, y las llamadas experiencias extraordinarias son una especie de llamarada que producen las brasas de las experiencias de la vida ordinaria.?

O como dice Martín Velasco: "El ser humano puede experimentar personalmente a Dios, y la pastoral debería tener presente esta meta inexorable, para ayudar al hombre a experimentar que siempre ha estado y sigue estando en contacto con Dios".

La experiencia de Dios es un saber inefable que escapa a las posibilidades del lenguaje como conceptos, pero el solo hecho de afirmar que es inefable ya está diciendo algo sobre Dios. También San Agustín decía que Dios es indecible, pero que con el solo hecho de decirlo, ya Dios no es indecible? . Esto significa que siempre se podrá decir algo de él, aunque nos encontremos con serias limitaciones de lenguaje; como bien afirma Ladriere al referirse a la experiencia que el ser humano tiene de Dios y que

${ }^{4}$ Ladrière, La articulación de sentido, 292.

${ }^{5}$ Macquarrie, God-talk, el análisis del lenguaje y la lógica de la teología, 95-96.

${ }^{6}$ González, "Mística medieval. El lenguaje teológico de ayer y de hoy", Capítulo III.

${ }^{7}$ Schillebeeckx, En torno al problema de Jesús. Claves de una cristología, 21.

${ }^{8}$ Martín Velasco, La experiencia de Dios hoy, 20.

${ }^{9}$ San Agustín, De doctrina christiana, 89. 
desea comunicar: “...no se puede recurrir a definiciones ostensivas, definiciones que consisten en indicar de qué objeto se habla" ${ }^{10}$.

Los místicos utilizan varios lenguajes para traer al presente la experiencia de algo que les ocurrió, misterio al que a fuerza de palabras intentan dar nombre. Uno de los lenguajes que transmite la experiencia del místico es la poesía. Esta le permite evocar el pasado, los sentimientos y recuerdos, con los cuales describe una relación íntima, de enamoramiento, de "aquello cuya aprehensión no pueden tener ni los sentidos ni el sentimiento, ni incluso el pensamiento, ni siquiera el pensamiento conceptual" ${ }^{11}$; o como lo dice Wittgenstein: "Hay, ciertamente, lo inexpresable, lo que se muestra a sí mismo; esto es lo místico" ${ }^{12}$.

Eso vendría a ser la capacidad que tiene el místico para traspasar las fronteras del lenguaje y mostrar que la experiencia de encuentro con Dios es valiosa por sí misma y no se circunscribe a ninguna búsqueda de beneficio personal o a una demostración de arrogancia.

En la escritura de los místicos encontramos un saber experiencial más que especulativo. Ellos hicieron una teología que recupera el relato y da paso a la imaginación. Su fuente de inspiración fue la Sagrada Escritura, testimonio narrativo de la experiencia de varones y mujeres que vivieron y compartieron su relación con Dios por medio de un lenguaje que informa lo que vive el ser humano en la cotidianidad de su vida.

La capacidad que tiene la persona de "crear" o "hacer hacer cosas con palabras" hace que su discurso sea poético, simbólico, visionario, de ficción, y dé orientación a la construcción de una teología narrativa y biográfica; también Wittgenstein lo decía: "Dios deja que el mundo discurra tranquilamente y entonces acompaña las palabras de un santo con una ocurrencia simbólica, con un gesto de la naturaleza” ${ }^{13}$.

Lo que viene de la experiencia del místico es la palabra sobre un Dios que se deja encontrar, un Dios que recupera la dimensión humana de los seres humanos mediante el encuentro con Jesús de Nazaret que el místico confiesa y que, en cierta manera, reproduce la experiencia de fe de los primeros creyentes.

Uno de los autores con mayor reconocimiento en la teología mística es Dionisio el Areopagita, quien -en su Corpus dionysiacum - desarrolla toda una teología mística. En ella, para hablar y nombrar a Dios hay que hacerlo por la vía negativa, en proceso ascendente, en el que el hombre se ve impulsado a asumir un camino de theosis o

\footnotetext{
${ }^{10}$ Ladrière, La articulación de sentido, 325.

${ }^{11}$ Ibíd., 329.

${ }^{12}$ Wittgenstein, Tratactus, 6.522.

${ }^{13}$ Barrett, Ética y creencia religiosa en Wittgenstein, 222.
} 
divinización. Con ello, busca hacernos patente que la luz está precisamente en la oscuridad, que el hombre constituye parte de un universo jerarquizado, en cuya cabeza está Jesús. A lo largo de toda su obra, el Areopagita insiste en que lo que ha salido del seno de la divinidad, un día, está llamado a volver a ella ${ }^{14}$.

Los místicos han llegado a la comprensión de que lo inefable es un conocimiento dado gratuitamente por el donante de la vida, y lo que saben es que el ser humano debe transformar su vida a la manera de Dios. San Bernardo de Claraval decía que si alguien había descubierto "algo" en su vida no podía quedarse quieto, pues la experiencia de Dios es dinámica y lleva al ser humano a seguirlo buscando sin cesar: "Tras la experiencia, continúa la búsqueda, porque esta nunca termina. Se busca a Dios en el ímpetu del deseo, en una ascensión interminable". ${ }^{15}$ De esta forma, ellos acuden a un lenguaje metafórico y kenótico para dar a conocer que Dios lo que busca es hacerse oír y darse al ser humano. Así corresponde a la teología hoy, como expresa el Concilio Vaticano II:

...el quehacer de los pastores y teólogos es escuchar con la ayuda del Espíritu Santo, y discernir e interpretar las varias voces de nuestro tiempo, y valorarlas a la luz de la Palabra divina, para que la verdad revelada, pueda ser mejor recibida, mejor comprendida, y expresada en forma más adecuada. ${ }^{16}$

El tema del lenguaje teológico no solo es preocupación de la teología cristiana; por ejemplo, en el ámbito del judaísmo ${ }^{17}$, el lenguaje y la experiencia mística constituyen una manera de ser y una forma de hacer teología. Alcanzar la débecut, o presencia de Dios y la contemplación de la gloria divina son la máxima aspiración del místico judío.

El místico, el santo, Simeón bar Yochai, o Yitsach Luria, no pierde su personalidad, pero en premio a su recto vivir, a su sabia interpretación de la Torah alcanza la visión de Dios, y, por tanto, la satisfacción de cuanto puede desear. El místico judío aspira a la visión intelectual, pero también a la visión sentimental y a la corporal, a ver literalmente a Dios, como lo vio Moisés en el Sinaí... ${ }^{18}$

De esta concepción de mística surge una manera de comunicar el mensaje divino, en la que se muestra claramente un acercamiento de Dios al hombre, la búsqueda de encuentro y de experiencia es iniciativa de Dios.

\footnotetext{
${ }^{14}$ Areopagita, Obras completas.

${ }^{15}$ San Bernardo, Sobre el cántico de los cánticos de Salomón, Scant 84, I, 5 parte 15.

${ }^{16}$ Concilio Vaticano II, Gaudium et spes 44.

${ }^{17}$ Tabuyo y López (trads.), Cábala. Nuevas perspectivas, 71.

${ }^{18}$ De Paz Blanco, "Lenguaje y experiencia en la mística judía”, 88.
} 
El encuentro con los varones y mujeres que la tradición cristiana reconoce como místicos es indispensable para dilucidar y aprender los movimientos que supone hacer teología. Hoy es fundamental entrar en constante ejercicio de análisis y de comprensión de la experiencia de Dios que -como sucede con un oficio- se tiene que aprender, estar en contacto con las fuentes del conocimiento, reflexionar sobre la propia experiencia y encontrar la mejor manera de transmitirla.

De ahí que hacer una teología desde la perspectiva de la experiencia y del lenguaje de los místicos se constituye en riqueza, porque -como bien se sabe- la teología es un ejercicio posterior de poner por escrito el reconocimiento de la experiencia que se tiene de Dios: de esa experiencia que el ser humano tiene, identifica, reflexiona, y comunica, en el sentido de escuchar, ver y tocar: "Lo que hemos visto y oído, eso os anunciamos, para que también vosotros tengáis comunión con nosotros: y nuestra comunión verdaderamente es con el Padre, y con su hijo Jesucristo" (Jn 1,3).

\section{Dios se da a conocer en el éxtasis o las visiones}

Las visiones han sido consideradas y estudiadas desde los puntos de vista de la psicología, la psiquiatría y la religión, entre otros, y no vamos a analizarlos aquí, ya que escapa a los objetivos del presente escrito.

Las visiones las comprendemos a partir de una experiencia personal del místico, sobre la cual este o esta informa en el marco de la fe cristiana. Las visiones tienen varias connotaciones:

- Son revelatorias, de carácter profético, de origen sobrenatural, y vienen cargadas de mensajes de transformaciones, ya sean personales o comunitarias. Se presentan como una necesidad urgente de dar un mensaje profético para cambiar y prevenir algo que está ocurriendo en la historia de los seres humanos.

- Otras son apariciones, de clarividencia: se ven y se reconocen imágenes que guardan estrecha relación con la enseñanza de la doctrina cristiana. Son visiones en la hay diálogos, y las imágenes se relacionan con la persona para motivar un cambio de vida.

- Las hay oníricas, en el sueño, cuando se perciben imágenes y se reciben mensajes que deben ser interpretados, "cuando un sosegado silencio todo lo envolvía y la noche se encontraba en la mitad de su carrera, tu palabra omnipotente, cual implacable guerrero, saltó del cielo, desde el trono real en medio de una tierra condenada al exterminio" ${ }^{19}$.

\footnotetext{
${ }^{19}$ Hass, Visión en azul. Estudios de mistica europea, 16.
} 
En la mayoría de casos, las visiones acontecen en medio de un éxtasis, en el cual el ser humano experimenta que sale de su orden natural hacia uno sobrenatural en el que puede sentir la presencia divina.

Para Dionisio el Areopagita Dios es un misterio y conocerlo también es un misterio. Por ello plantea:

... solo se accede a Dios en ocasión de un éxtasis personal intransferible, una intuición espiritual, experiencia de pocos, o en el momento escatológico, tras una búsqueda de amor. De ahí que el conocimiento es místico, no bastan, aunque son necesarias, ni la vía afirmativa, ni la vía negativa, ni la hipernegación, sino a través de la agápesis unión. ${ }^{20}$

Este autor recalca que la experiencia es personal, que el místico decide buscar el amor de Dios y este es dado en cualquier momento de manera gratuita y desbordada. Aquí hay un esfuerzo humano por encontrarse con Dios y el premio de este esfuerzo es la unidad que se da mediante el éxtasis. De él se puede decir que "es el grado supremo en el acceso a Dios, sea como don transitorio en la tierra o como definitivo en la vida escatológica" ${ }^{21}$.

Esto nos remite a la fuente bíblica, la cual revela experiencias de éxtasis como las de Moisés (Ex 3), Jacob (Gn 28,11), y Pablo (2Co 12,2), en las que la manifestación de Dios se da de manera nítida, y el místico ve, escucha y luego interpreta que Dios estaba ahí, pero que no se había dado cuenta de su presencia.

En la historia de la mística cristiana se encuentra el conocimiento de una experiencia que tiene fuerza constativa, cuya palabra es comprendida como verdad, y que mueve a los oyentes a entrar en un mundo de significaciones, adhesiones y conversiones. Varones y mujeres han mostrado una manera de vivir el Evangelio a partir de opciones fundamentales. Los místicos han dejado una herencia de vida espiritual, con senderos recorridos para que el creyente puede aprovechar en su peregrinaje por la vida cotidiana. También han transmitido experiencias extraordinarias de visiones en las que se revela una manera de ser de Dios y de relacionarse con el ser humano.

En sus visiones, los místicos manifiestan deseos de unión con él, pero justamente a Dios no lo ven, sino escuchan voces representadas en imágenes ya sean de ángeles o de aves, como el águila:

Vi una gran águila que, desde lo alto volaba hacia mí y me dijo: "Si quieres acceder a la unión, prepárate". Me quedé de rodillas mientas mi corazón latía

\footnotetext{
${ }^{20}$ Areopagita, La jerarquía celestial, la jerarquía eclesiástica, la teología mistica, 335.

${ }^{21}$ Ibíd., 341.
} 
terriblemente, para adorar inmensamente al Amado. [...]. El águila se volvió diciendo: "El que ha venido, vuelve; y donde nunca llegó, jamás llegará". ${ }^{22}$

Las visiones revelan los estados de ánimo del místico, pero también expresan los más profundos anhelos en la búsqueda de una unión con Dios. La preocupación fundamental es dar a conocer una vivencia personal con Dios y encaminar a otros para que hallen, en su interior, el fundamento divino que los constituye.

Las visiones se establecieron en un lenguaje que comunicó el amor de Dios en el tiempo y en las circunstancias en que vivían los seres humanos. La época visionaria de los siglos XIV al XVII mostró la necesidad de apropiarse de los recursos literarios y de las dinámicas espirituales para ofrecer una teología autobiogáfica y narrativa, en la que los místicos enfatizaron la comunicación divina como un hecho verdadero y posible de experimentar:

Vi una gran unidad entre Cristo y nosotros. Pues cuando él sufría, nosotros sufríamos, y todas las criaturas capaces de sufrir sufrían con él. Es decir, todas las criaturas que Dios ha creado para nuestro servicio, el cielo y la tierra suspendieron sus funciones naturales debido a la tristeza de la muerte de Cristo, pues es su característica natural reconocerle como su Señor, en quien reside todo poder. ${ }^{23}$

Detrás de cada uno de los textos que describen el éxtasis o las visiones subyace un mensaje teológico que deja en segundo lugar la visión propiamente dicha, para dar paso al mensaje que Dios quiere comunicar. Sin embargo, aparece lo indescriptible y la inefabilidad para pronunciar las palabras; el mismo Pablo así lo dice: “...fue arrebatado al paraíso y oyó palabras inefables que el hombre no puede pronunciar” (2Co 12,4).

Un aspecto importante y común consiste en que la manifestación de Dios ocurre con frecuencia en el sueño, o mejor, el místico informa que lo que ha visto y oído era como en un sueño. Abundantes son los textos del Antiguo y Nuevo Testamento que relevan la teofanía de Dios de esta manera: el sueño de José (Gn 37,5-10), que predice el futuro; el misterio que le fue revelado a Daniel en un sueño, en el que él bendice a Dios (Dn 2,19ss.).

También la manifestación de Dios se da en condiciones concretas en las que viven las personas: la situación de Elías de sometimiento al Imperio, contexto en el cual se le revela Dios (1R 18,46); o en Ezequiel, quien tiene la visión del carro de Yahveh, con un universo lleno de simbolismos en el que descubre el poderío divino $(1,3 ; 3,22 ; 8,1 ; 33,22)$.

\footnotetext{
${ }^{22}$ De Amberes, Flores de Flandes, 173.

${ }^{23}$ Norwich, Libro de visiones y revelaciones, 78 .
} 
También, en los relatos de la anunciación, el sueño de José es revelatorio del Mesías que está por venir: a José se le revela la verdadera identidad del niño Jesús y su actitud es de obediencia a la palabra que le es dada (Mt 1,20-25; 2,19-23); y a los pastores se les presenta el ángel, envolviéndolos con su luz para anunciarles una gran alegría (Lc 2,8-10).

En la tradición de la mística cristiana, la referencia a la Sagrada Escritura es imprescindible. Los místicos se mueven en el marco de la Palabra revelada para evocar que lo mismo que los escritores sagrados vivieron y sistematizaron, lo han vivido ellos. Pastor de Hermas ${ }^{24}$ comunica las visiones en términos apocalípticos y exhorta al cuidado de los otros y a tomar partido por el Evangelio:

Vivid en paz unos con otros. Cuidad los unos de los otros. [...]. ¡Atención al juicio que se avecina! Los que tenéis en abundancia, buscad a los hambrientos, mientras no se termine todavía la torre. Una vez terminada la construcción, buscaréis hacer el bien y no tendréis ya tiempo. (Vis 3.9.2-5)

Esta es una clara invitación a compartir los bienes y a hacer justicia con todos, como dice Mateo: "Si quieres ser perfecto, anda, vende tus bienes y dáselos a los pobres, y tendrás un tesoro en los cielos. Luego sígueme” (Mt 19-21).

Pacomio ${ }^{25}$, el monje, busca alentar a sus hermanos para que vivan en perfecta castidad mediante la humildad y el dominio de las pasiones. Él describe sus visiones justamente en la lucha que debe librar en su pensamiento frente a los grandes deseos de poseer y sentir la presencia corporal de la belleza femenina. La concupiscencia nunca ganará la batalla al monje, quien ha sabido reservarse solo para Dios, y si en la visión vence, en la vida comunitaria, también lo hará.

Posteriormente, en la Edad Media, se destaca la presencia de la mujer con sus éxtasis y visiones; las tuvieron monjas, laicas, mujeres obreras quienes encontraron una manera de hablar de Dios con autoridad por lo que veían y escuchaban. Fueron las que rompieron esquemas en una sociedad marcada predominantemente por la producción teológica masculina. Entre ellas se destacan las siguientes: Isabel de Schönau (+ 1164); Hildegarda de Binguen (+ 1179); María de Oignies $(+1213)$; Beatriz de Nazareth (+ 1268); Hadewijch de Amberes (+1260); Matilde de Magdeburgo (+ 1282); Matilde de Hackenborn (+ 1299); Gertrudis de Hefta (+ 1301); Ángela de Foligno (+ 1309); Margarita Porete (+ 1310); Brigida de Suecia $(+1373)$; Caterina de Siena $(+1380)$; Juliana de Norwich (+ 1416); Margarita de Kempe (+ 1440).

\footnotetext{
${ }^{24}$ Ruiz Bueno (traducción e introducción), El pastor de Hermas.

${ }^{25}$ Deseille y Bianchi, Pacomio, e la vita comunitaria.
} 
El universo visionario de Hildegarda es amplio, en su gran obra Scivias. Conoce los caminos y describe las visiones mediante imágenes que recrean el pensamiento del que se acerca a su lectura; son imágenes de la naturaleza, los árboles, las aves, el agua, el sol, el viento, las construcciones y los tronos, que indican el poder y la majestuosidad de quien le habla y le revela los secretos más íntimos. Las visiones van acompañadas de mensajes para ser enseñados.

Así, después de hacer la representación de la visión, ella da un mensaje contundente: "Yo te revelo y te digo esto: mira, ve y anúncialos, enséńalos y que se enciendan los corazones de fuego de los fieles, que son las piedras más puras para edificar la Jerusalén celestial"26. La visión aquí es un pretexto para enseñar y sistematizar una manera de hablar sobre Dios. Las visiones de Hildegarda muestran una verdadera acción pedagógica, en tanto que no ahorra recursos para ilustrar el conocimiento de un Dios que, preocupado por el ser humano, se da a conocer de muchas formas.

Ángela de Foligno habla de la experiencia de Dios-amor que lleva al ser humano a experimentar con locura su ausencia. Esta mujer, en su encuentro personal con Dios, lo descubre lleno de ternura, con palabras que se repiten y que le recuerdan que ella es la hija amada, pero que a su vez, eso que ve, no lo sabe describir y se refiere como amor no conocido:

He visto una plenitud, una majestad inmensa, que no se describir. Me parecía fuese "todo bien". Al alejarse, me dijo muchas palabras de dulzura, y se alejó con indecible suavidad, lentamente, poco a poco. Fue entonces al ausentarse, cuando comencé a lanzar voces y gritos, y sin ningún pudor vociferaba y clamaba repitiendo esta frase: "Amor no conocido", ¿̨por qué me abandonas? No era capaz de decir otra cosa. ${ }^{27}$

Por su parte, Hadewijch de Amberes es herida por el amor de Dios, y esta herida le recordará el Dios-amor y amante del que ella se ha fiado siempre. A ese Dios le escribe con su mejor género literario. Las visiones revelan los diálogos personales entre ella y Dios. Él quiere algo para ella y ella comprende que no se puede quedar contemplando la divinidad de Dios, sino compartir e imitar su humanidad como Jesús lo hizo aquí en la tierra. Hadewijch asume una postura crítica frente a lo que significa vivir desde Dios, en tanto que es más fácil ver la divinidad fuera de uno mismo y no en nuestra propia condición humana. Por tanto, asumir la divinidad en la corporalidad significa la integración de todo nuestro ser como el lugar propicio en el que Dios, nuestro Padre, se nos revela y nos hace verdaderamente humanos.

\footnotetext{
${ }^{26}$ De Binguen, Scivias. Conoce los caminos, 371.

${ }^{27}$ Santa Ángela de Foligno, Experiencia de Dios amor, 48.
} 
Hadewijch es maestra y lo que ella ve lo describe con la intención pedagógica de conducir al ser humano al encuentro con Dios y a vivir con él. Ella enseña y explica el significado de cada una de las cosas que vio, pues cada imagen tiene un sentido. Cada imagen compromete los sentidos, y esto muestra que la corporalidad se presenta como posibilidad de la captación mística. También ella experimenta la no totalidad del misterio y de la inefabilidad del mismo:

Lo que yo puedo expresar no es nada. La inmensidad de su belleza, el excesivo dulzor de su rostro augusto y admirable me impide cualquier palabra o imagen. Y mi Amado se dio a mí, así que le pude comprender y sentir. Pero cuando lo vi, caí a sus pies, pues comprendía que había sido llevada en este camino y todavía tenía que vivir mucho antes de acceder a él. [...]. Pero él me dijo levántate. Tú has deseado estar unida a mí y te has esforzado por esta unión en todos los caminos. (Vis 1$)^{28}$

Hadewijch enfatiza en la capacidad del ser humano para captar el misterio, debido a que fuimos creados como seres abiertos y templos donde a Dios le agrada habitar. Más que un esfuerzo personal por buscar la unión con Dios, está el reconocimiento que el mismo ser humano tiene de que Dios se le ha dado, está ahí, se muestra en cada acción, y para ello se requiere apertura y aceptación para entrar en diálogo con él.

Juliana de Norwich recibe una revelación de Dios y durante su vida reflexiona porque entiende que el ser humano puede llegar a tener muchas experiencias pero, si no reflexiona sobre ellas, no se da un aprendizaje y una comprensión del misterio. No se avergüenza de decir lo que deseó, preguntó, escuchó, vio y sintió desde lo más profundo de sus entrańas. Esta mujer hizo una teología del sufrimiento que pasa por la cruz:

Y me pareció que el dolor más grande, el último dolor de su pasión, fue cuando su carne se secaba. Y en ese irse secando, vinieron a mi mente las palabras de Cristo: tengo sed. Vi en Cristo una doble sed, una física, otra espiritual. ${ }^{29}$

Las visiones recrean y recuerdan lo que se ha escuchado de la Palabra de Dios y la enseñanza en la tradición de la Iglesia, pero dan un plus: la libertad con la que juegan los místicos por medio de imágenes y palabras para profundizar y transmitir un mensaje en el que el ser humano es protagonista.

En el siglo XVI, Santa Teresa de Jesús, visionaria también, no sabe dar razón con la precisión que quisiera sobre lo que está experimentado, y tiene que acudir a un gran letrado para despejar sus dudas sobre la visión en la que ella no parece estar presente.

\footnotetext{
${ }^{28}$ De Amberes, Visiones, 155.

${ }^{29}$ Norwich, Libro de visiones y revelaciones, 74-75.
} 
Acaecióme a mí una ignorancia al principio; que no sabía que estaba Dios en todas las cosas; y, como me parecía estar tan presente, parecíame imposible. Dejar de creer que estaba allí, no podía, por parecerme casi claro había entendido estar allí su misma presencia. Los que no tenían letras, me decían que estaba solo por gracia. Yo no lo podía creer, porque, como digo, parecíame estar presente, y así andaba con pena. Un gran letrado de la orden del glorioso Santo Domingo me quitó esta duda, que me dijo estar presente, y cómo se comunicaba con nosotros, que me consoló harto. ${ }^{30}$

Teresa de Jesús tiene un estilo pedagógico para describir lo que vio y la necesidad de conducir al ser humano para que este reoriente su vida:

...estando un día en oración me hallé en un punto toda, sin saber cómo, que me parecía estar metida en el infierno. Entendí que quería el Señor que viese el lugar que los demonios allá me tenían aparejado, y yo merecido por mis pecados. ${ }^{31}$

Son varias las visiones que Santa Teresa libra entre las que impactan directamente el intelecto, las que impactan su corporalidad y las que pueden llamarse imaginarias: El libro de la vida es prueba de ello. Da crédito a todas sus visiones como una manera de Dios de estar con ella, conducirla y llevarla a ejercer una función mistagógica. Teresa aprende y enseña, descubre e interpreta la acción de Dios en ella como un saber que necesita ser comunicado. Podríamos seguir ahondando en su pensamiento y en el de muchos más autores contemporáneos, varones y mujeres que revelan la comunicación que tienen con Dios, en la que ellos y ellas se autoimplican y se sienten responsables de la salvación de sus hermanos.

El autor anónimo de La nube del no saber llega a la conclusión de que los seres humanos han sido creados con posibilidades para percibir la presencia de Dios, aunque esta les sobrepase, como lo expresaba el salmista (Sal 138). Los seres humanos pueden llegar a advertir que "algo" en su vida les falta, "algo" considerado fundamental, que da sentido y llena la vida de gratuidad. La necesidad de ese "algo" ocurre muy a menudo. ${ }^{32}$

En la mística contemporánea no se encuentran propiamente alusiones a visiones como las que se han venido describiendo, pero sí referencias de los místicos sobre una experiencia del amor de Dios que los lleva a una conversión profunda, a un cambio de mentalidad y a una entrega sin límites hacia los demás. Se puede citar aquí a Edith Stein, a Simone Weil, a Etty Hillesum, a Carlos de Focualt, a Monseñor Romero y a Teresa de Calcuta entre otros.

\footnotetext{
${ }^{30}$ Santa Teresa de Jesús, Obras I, 135.

${ }^{31}$ Ídem, El libro de la vida, 283

${ }^{32}$ Anónimo inglés (siglo XIV), La nube del no saber y el libro de la orientación particular.
} 
Todos han sido personas que -como ellos mismos dicen- han despertado al Dios que estaba dentro, han descubierto una dimensión importante en sus vidas y la han potenciado al máximo, con su generosa entrega, sabiéndose necesitados de los otros, quienes son los que ayudan a despertar al Dios preexistente en la vidas de los seres humanos.

\section{Dios se da a conocer en la kénosis o el aniquilamiento/desasimiento del ser humano}

Acudimos a la palabra kénosis para referirnos a desasimiento, anonadamiento, aniquilamiento, vaciamiento, abandono y desprendimiento. Todos estos términos, en el vocabulario de los místicos, significan un proceso o un camino que el ser humano recorre para llegar a ser la imagen y semejanza de Dios.

En otras palabras, los místicos buscan transmitir que la única manera que tiene el ser humano para llegar a ser imagen y semejanza de Dios es la kénosis ${ }^{33}$. Solo en el desprendimiento o vaciamiento de todo lo que ama, ata, o apega, el varón y la mujer pueden encontrarse y descubrir la divinidad presente en ellos. La kénosis es el mejor medio para llevar una vida obediente y confiada en Dios.

La kénosis supone un camino en libertad y humildad para reconocer que en la corporalidad está la presencia divina de un Dios que se entrega al ser humano y lo llama a asumir la condición de hijo en un seguimiento que necesariamente pasa por la aniquilación o desasimiento, por el camino de la cruz, que es la renuncia al propio yo humano (Ich-bindung/Ichsucht). De ahí que el aniquilamiento, desasimiento o kénosis sean poco comprensibles a la razón humana, dado que entre más uno se reduzca a la nada más podrá reproducir los rasgos de Jesús en su vida.

Los místicos inauguran una corriente teológica del aniquilamiento, desasimiento o anonadamiento del ser humano que conduce a la unión con Dios. Es importante destacar que ellos reconocen la criaturalidad del ser humano quien, en su condición terrena, se encuentra limitado y con una clara tendencia a equivocarse; además, está asediado constantemente por las tentaciones, lo que lo hace aún más vulnerable.

Sin embargo, esta misma fragilidad radical puede llegar a ser un punto de partida para el encuentro con su Creador, pues la cuestión no está en la labilidad, sino en la libertad que el ser humano tiene para elegir el camino del bien. En este sentido, la

\footnotetext{
${ }^{33}$ Los místicos no utilizaron la palabra kénosis; hablaron de aniquilamiento y desasimiento, pero estos eran equivalentes al lenguaje que San Pablo utilizó para referirse a la negación del yo en función de la voluntad divina. Hacemos uso del término kénosis en tanto que es el de más uso en la nuestra teología contemporánea, sin que por ello no mencionemos los otros términos como sinónimos.
} 
"lucha contra las tentaciones" no es vista como control de la naturaleza humana, sino como dominio sobre las acciones humanas.

Como representantes de esta mística del aniquilamiento y del desasimiento se pueden citar dos maestros medievales: Margarita Porete y Maestro Eckhart. Ellos hacen una teología que cuestiona los esquemas y las concepciones que se venían desarrollando sobre la relación del ser humano con Dios; ponen la kénosis como la obediencia en el centro del seguimiento a Jesús, cuando el ser humano, por puro desasimiento de sí, deja que el amor de Dios penetre en su interior y le haga semejante a él.

Así, la persona desasida es esa que se desprende de su propio yo, que obedece mediante la escucha y que da paso a la voluntad de Dios. Porete y Eckhart insisten en que todo lo que tenemos es dado, en que hay un donante que es Dios, y en que lo único que debe hacer el ser humano es desposeerse de sí mismo, reducirse a la nada, para dejar que Dios lo habite y allí se dé la unión con él.

Margarita Porete, una mujer perteneciente al movimiento de las beguinas, leyó, interpretó y enseñó la Sagrada Escrita. Su única obra escrita, El espejo de las almas simples, y sus enseñanzas fueron el motivo por el cual la Inquisición la llevó a la hoguera, en París, en 1310, tras ser acusada de herejía. Margarita fue una mujer apasionada con los temas de la Trinidad y el aniquilamiento, y usó un lenguaje alegórico para referirse a la relación del alma aniquilada con Dios. Son figuras principales de su obra la Dama Amor, Lejos-Cerca (personajes divinos) y el Alma Aniquilada (el ser humano).

Del Alma Aniquilada, la Dama Amor dice que es divina, no por naturaleza, sino por gracia. Aun así, esta comprensión de la trinidad es notable por la manera en que rompe con modelos androcéntricos, así como por el hecho de que la divinidad habla a través del espejo en la voz de la Dama Amor, un personaje femenino. ${ }^{34}$

En su obra, Porete precisa el tema del aniquilamiento del alma, la cual encuentra en el vaciamiento interior la mejor manera para conocer a Dios y vivir desde él. Una vez anonadada, el alma solo se preocupa de Dios y no busca consuelos, ni intermediarios ajenos a él.

El alma libre si no quiere no responde a nadie que no sea de su linaje; pues un gentilhombre no se dignaría a responder a un villano que lo retara o requiriera

\footnotetext{
${ }^{34}$ Beneito, Piera y Barcenilla, Mujeres de luz. La mistica femenina y lo femenino en la mistica, 150. "En otros lugares se dice que el autor es la Dama Amor, Dios mismo, hablando a través del alma aniquilada de Marguarite [...] desafió la construcción masculina de la deidad y ofreció una brillante alternativa del lenguaje 'Dios-él, él varón' que tanto ha prevalecido en el mundo institucionalizado, simbolizado en El espejo por este personaje de la Razón”.
} 
a batalla; por ello, quien reta a un alma, así no la encuentra, sus enemigos no obtienen respuesta. El alma libre que está con Dios no necesita de nada. ${ }^{35}$

El alma vive la libertad cuando comienza un viaje en busca del Amado. Tal viaje puede tener asensos y caídas, pero justamente en las subidas y las bajadas el alma se libera de sí misma, se pone a prueba y descubre que es capaz de reconocer la divinidad, gozar de ella y de quedarse en su compañía, porque "el divino amor de unidad engendra en el alma anonadada, en el alma liberada, en el alma clarificada, substancia permanente, fruición agradable y amorosa conjunción”. ${ }^{36}$

Ser libre es algo deseable por el ser humano; de ahí que el viaje en esta vida sea una aventura apasionante, al experimentarse la caída y la capacidad para levantarse y continuar. En su camino, el ser humano descubre que no puede parar, porque la búsqueda del Amado continúa. Con ello, la maestra Porete quiere dar a entender que la naturaleza humana no es autónoma, que todo cuanto tenemos es recibido y, por tanto, mientras estamos de paso en esta vida que conocemos necesitamos certezas para pensar y vivir humanamente.

La teología de la maestra Porete evoca una relación personal con Dios, en la que el alma sabe lo que debe hacer, cómo vivir y comportarse en el mundo desde la perspectiva de ser una con él: “...el alma en virtud de la fe sabe lo que le conviene para su salvación” ${ }^{37}$. En este sentido, el alma siempre busca mantener una relación de unión con Dios, y no opta por el alejamiento de él o por la ruptura porque sabe que, al excluir a Dios, se encerrará en sí misma y asumirá la soledad.

El alma sabe que es mejor estar con Dios y vivir la solidaridad, la compasión, la misericordia, el respeto por el otro, la responsabilidad con el cuidado de la naturaleza, el reconocimiento de la dignidad de los otros, los cuales serán el mejor espejo de un alma simple y anonada que ha sido tocada por Dios. El alma que tiene a Dios es libre, su voluntad está anclada en él, pero,

...¡¿cuándo están esas almas en la recta libertad del puro Amor? Cuando no tienen deseo alguno, ni ningún sentimiento, ni padecen en ningún momento el menor apego al espíritu; pues esta práctica las esclavizaría, ya que está muy lejos de la paz de la libertad a la que pocos se abandonan. [...]. Tales almas son únicas en todo y comunes en todo, pues no pierden su estado de libertad por algo que les acontezca. ${ }^{38}$

\footnotetext{
${ }^{35}$ Porete, El espejo de las almas simples, 134.

${ }^{36}$ Ibíd., 160.

${ }^{37}$ Ibíd., 70 .

${ }^{38}$ Ibíd., 78.
} 
Así la maestra Porete consigue explicar que el alma libre es la que se abandona a la voluntad de Dios y a la que nada esclaviza, porque tiene a Dios, y "quien tiene a Dios, lo tiene todo, y por ello se dice que no tiene nada, porque todo lo que el alma tiene de Dios en ella, por el don de la gracia divina le parece nada y es nada al lado de aquello que ella ama en él" ${ }^{39}$.

Toda la obra de Porete esboza un camino de libertad por medio de diálogos, alegorías, monólogos y textos autobiográficos, para mostrar lo que ocurre con el alma anonadada y la unidad, donde ya no hay Dios, ni alma, sino que todo es gozo y plenitud:

A quien preguntase a estas almas libres, seguras y pacíficas si querrían estar en el Purgatorio, le responderían que no; si querrían estar en esta vida con la certitud de salvarse, le responderían que no; o si querrían estar en el Paraíso, le responderían que no [...] tales almas no se saben encontrar buenas o malas, ni tienen conocimiento de sí mismas, ni sabrán juzgar si han sido convertidas o pervertidas. ${ }^{40}$

Para llegar a ese estado, el ser humano debe estar libre. Ello significa haber visto su vida y su relación con Dios en clave del pasado y reconocer que Dios ha estado en las coincidencias de su vida, habitándolo y sosteniéndolo:

Pues solamente soy lo que Dios es en mí y no otra cosa, y Dios es lo mismo que eso, que él es en mí; pues nada es nada, pero lo que es, y por ello si soy, no soy sino lo que Dios es; y nadie es sino por Dios; por ello no encuentro más que a Dios allí donde penetró, pues a decir verdad, nada hay sino Dios. ${ }^{41}$

Para la maestra Porete es fundamental la comprensión que debe tener el ser humano para llegar a ser uno con Dios. No se trata de dar o recibir, o de hacer grandes esfuerzos para obtener los dones divinos, sino prestar atención a la vida, reconocer la profundidad de su maldad, y principalmente saber que Dios ya lo ha dado todo, que no le pide ni le exige nada. El ser humano sabe que el aniquilamiento o la kénosis es la mejor opción para seguir afirmando a Dios en su vida.

El Maestro Eckhart -quien también fue cuestionado por su pensamiento teológico- coincide con muchos de los planteamientos de Margarita Porete. Es necesario tener en cuenta que sus reflexiones teológicas fueron enriquecidas por el contacto que tuvo con las mujeres, especialmente con el movimiento de las beguinas ${ }^{42}$.

\footnotetext{
${ }^{39}$ Ibíd., 67.

${ }^{40}$ Ibíd., 58.

${ }^{41}$ Ibíd., 118.

42 "Lo que si puede afirmarse es que fue el contacto con las beguinas y monjas dominicas lo que motivó a Eckhart a desarrollar una teoría sobre la unidad del hombre con Dios, y de esta manera el surgimiento de una corriente mística" (Mañon, "Eckhart y la espiritualidad de las beguinas").
} 
El encargo que había recibido de atender espiritualmente a estas religiosas hizo que su público fuera mayoritariamente femenino.

Por eso, con ellas compartió sus inquietudes, que se fundamentaban en el estudio y la interpretación de la Sagrada Escritura, en el diálogo sobre las experiencias espirituales y en lo que acontecía en la vida cotidiana de las personas. Temas como el abandono o renuncia al yo, la unidad del hombre con Dios y la perfección humana hallan gran similitud entre las maestras místicas beguinas y el pensamiento del maestro Eckhart.

Todo el eje central de su teología está en el desasimiento, en el sentido de que, con este, el ser humano no es susceptible a nada que no sea Dios. Así, el desasimiento viene a significar libertad y unión con Dios. Para que el ser humano llegue a sentirse libre, es necesario que no aspire a nada, ni siquiera a recibir gracias o dones de Dios: “...que uno aprenda a desasirse de sí mismo hasta no tener ya nada propio”³.

Sea cual fuere el camino, o el modo en el seguimiento de Jesús, para el maestro Eckhart es importante la humildad y el vaciamiento; humildad para reconocer que en su cuerpo está la presencia divina de un Dios que se entrega y que lo llama a asumir la condición de hijo en un seguimiento que necesariamente pasa por la kénosis o el desasimiento, por el camino de la cruz, por la renuncia al propio yo humano:

Cuando predico suelo hablar del desasimiento y del hecho de que el hombre se libre de sí mismo y de todas las cosas. En segundo término [suelo decir] que uno debe ser in-formado otra vez en el bien simple que es Dios. En tercer término, que uno recuerde la gran nobleza que Dios ha puesto en el alma para que el hombre, gracias a ella, llegue hasta Dios de manera milagrosa. En cuarto término [me refiero] al resplandor que hay en la naturaleza divina, es cosa inefable. ${ }^{44}$

Se trata de un vaciamiento de todo lo que esté al alcance de la persona: el mundo, los otros, ella misma y los esquemas o imágenes representativas de Dios. El ser humano debe tener en cuenta que su única unión es con el dador de la vida, porque en la medida en que nos vayamos despojando o vaciando, dejamos que la divinidad nos ocupe. De esta manera comprendemos que el desasimiento es una clara invitación a liberar la conciencia de angustias y temores, de reproches y castigos. El alma ha sido creada para compadecerse de ella y para verse con ojos de misericordia, tal como Dios la ve.

El desasimiento está relacionado con la obediencia a la voluntad de Dios, obediencia que es la mayor virtud y logra la perfección de toda gran obra. No una

\footnotetext{
${ }^{43}$ Maestro Eckhart, Obras alemanas. Tratados y sermones, 695.

${ }^{44}$ Ibíd., 141.
} 
obediencia a normas y mandatos, sino a la aceptación de la voluntad de Dios en la vida del ser humano.

El maestro Eckhart lo resume de la siguiente manera:

Siendo obediente, un hombre se purifica a sí mismo, y Dios penetra en él; ya que al no tener voluntad propia, Dios dispondrá para él lo que dispondría para sí mismo, Dios elige por mí. [...] y continúa diciendo: allí donde el hombre, en obediencia, sale de su yo y se deshace de lo suyo, justamente allí Dios, a su vez, debe entrar por fuerza; pues cuando alguien no quiere nada para sí, Dios tiene que querer en su lugar, de la misma manera que para él mismo. Cuando me he desasido de mi voluntad y cuando no quiero nada para mí mismo, entonces Dios debe querer en mi lugar. ${ }^{45}$

Sin desconocer la condición humana, de fragilidad y de pecado, el Maestro Eckhart encuentra en ella el camino que conduce a la kénosis.

Pues, cuanto más débil se halle el hombre y cuanto más haya pecado, tanta más razón tiene para vincularse con Dios mediante un amor indiviso en el cual no hay ni pecado ni imperfección. El mejor escalón, pues, que se puede pisar, cuando se quiere ir hacia Dios con plena devoción, es el estar sin, pecado en virtud del arrepentimiento divino. ${ }^{46}$

En toda su teología, Eckhart busca la manera de comprender que el desasimiento lleva a encontrar a Dios en la realidad de ser uno con él: "El corazón desasido no desea nada en absoluto, tampoco tiene nada en absoluto de lo cual quisiera ser librado" ${ }^{47}$. Y coincide con las ideas de Margarita: un alma que ha logrado desasirse sabe que Dios ya lo dio todo y tiene todo para ser libre y para ser feliz:

He investigado con seriedad y perfecto empeño cuál es la virtud suprema y óptima por la que el hombre es capaz de vincularse y acercarse lo más posible a Dios [...], y no encuentro sino que el puro desasimiento supera todas las cosas, pues todas las virtudes implican alguna atención a las criaturas, en tanto que el desasimiento se halla libre de todas las criaturas, [...] y no es susceptible de nada que no sea Dios. ${ }^{48}$

El desasimiento es entonces el mejor camino para que Dios sea y ocupe a todo el ser humano; así se muestra lo propiamente humano, la dependencia y la receptividad frente a Dios. Se trata de salir de nosotros mismos, para dejarlo que sea, en nosotros, pues no puede haber nada mejor ni superior al hombre que su total disponibilidad

\footnotetext{
${ }^{45}$ Ibíd., 64.

${ }^{46}$ Ibíd., 79.

${ }^{47}$ Ibíd., 250.

${ }^{48}$ Ibíd., 237.
} 
para con Dios. Dice el maestro Eckhart: “...aférrate a Dios, y él te dará todo lo bueno por añadidura” ${ }^{\text {‘9 }}$. Así pone al hombre en una actitud básica frente a Dios: una actitud de desasimiento, de obediencia y de sumisión a la voluntad divina,

...que no debe entenderse como la renuncia a mi propia voluntad en favor de una voluntad opuesta, sino como el perfeccionamiento que de mi voluntad hace Dios; yo renuncio realmente a mi voluntad, pero la vuelvo a encontrar perfecta y plena, en la voluntad de Dios. Esta es la única vía hacia la verdad y la comunicación con Dios. ${ }^{50}$

De esta manera, el desasimiento es libertad, transitar la vida bien encaminado:

Debes saber que el verdadero desasimiento no consiste sino en el hecho de que el espíritu se halle tan inmóvil frente a todo cuanto le suceda, ya sean cosas agradables o penosas, honores, oprobios y difamaciones, como es inmóvil una montaña de plomo ante el soplo de un viento. ${ }^{51}$

El maestro Eckhart no se queda en el puro desasimiento sin tener en cuenta la condición humana que nos acompaña y que nos lleva a avanzar y a retroceder en el camino de kénosis. Por tanto, entran también, en su pensamiento teológico, la culpa y el pecado, fruto de la condición humana, que se dan por el deseo de posesión y la pérdida de la conciencia de la interioridad divina.

Aun así, Eckhart descubre que, en el pecado, el hombre siente la angustia de la nada, y sentirla y comprenderla le lleva a recogerse en su interior y a recomponerse por dentro:

...el círculo espiritual no se afianza si él no reconoce el llamado de la angustia y con un acto de amor y de entrega no se libera del golpe de su pecaminosa aflicción y de sus motivos prácticos y se adhiere con un acto de voluntad a la voluntad de Dios identificándola con esta. ${ }^{52}$

También recuerda que por nuestras propias fuerzas e iniciativas no emprendemos el camino del desasimiento y de liberación, pero Dios mismo nos conduce y nos atrae hacia él:

Nadie debe pensar que es difícil llegar, aunque al oír hablar de ello parece grande y difícil. Bien es cierto que al principio el desprendimiento es un poco difícil, pero cuando se avanza, nunca la vida fue tan fácil, ni tan alegre, ni tan amable y Dios se emplea a fondo en permanecer constantemente cerca del hombre, en

\footnotetext{
${ }^{49}$ Ibíd., 279.

${ }^{50}$ Flórez, La ética de Meister Eckhart, 25.

${ }^{51}$ Maestro Eckhart, Obras alemanas. Tratados y sermones, 145.

${ }^{52}$ Faggin, Meister Eckhart y la mistica alemana medieval, 70-71.
} 
instruirlo, con el fin de conducirle, si el hombre quiere seguirle. [...]. Dios está dispuesto en todo tiempo, pero nosotros estamos muy poco dispuestos. Dios está cerca, pero nosotros estamos lejos, Dios está en el interior, pero nosotros estamos fuera. Dios nos es íntimo, pero nosotros somos extranjeros. ${ }^{53}$

Porete y Eckhart están insertos en el pensamiento paulino, para mostrar el sentido profundo de despojo, la renuncia voluntaria, tanto de lo divino como de lo humano presente en Cristo, quien se hace siervo, "se despoja de sí mismo tomando condición de esclavo" (Flp 2,7), y asume de manera radical la condición humana.

Así, la kénosis o el aniquilamiento en Margarita Porete o el desasimiento en Maestro Eckhart son interpretados como la negación del yo para que la divinidad toque la humanidad, pues solo muriendo para sí mismo, el hombre puede comprender el amor de Dios; y solo en el vacío más profundo, el hombre puede experimentar la presencia divina, de la que nos habla Pablo: "Yo ya no vivo, pero Cristo vive en mí" (Ga 2,20).

\section{Conclusión}

El lenguaje teológico de los místicos de otras épocas y de otras culturas desafía la comprensión que se tiene de la realidad en el momento presente.

La teología latinoamericana, tan atenta a la lectura de la realidad humana y de los "signos de los tiempos", se puede ver enriquecida por la reflexión teológica de quienes han precedido en siglos pasados, en especial por una reflexión tan original y crítica de varones y mujeres, místicos y visionarios, quienes desde su condición y circunstancias de su tiempo comprendieron que los seres humanos son el hogar de Dios, y la kénosis (aniquilación, desasimiento) como camino para llegar a esa unión con él.

Esta comprensión diferente y radical resulta sumamente esclarecedora en un momento en el que la antropología se desencanta del antropocentrismo y se inclina fuertemente por una visión integral, espiritual, ecológica, contextual y situacional del ser humano y de su destino en la historia.

Nos hallamos ante la necesidad de ofrecer una teología de orden autobiográfico, sapiencial y simbólico que narre experiencias y transformaciones; porque quien hace teología entrega una palabra, comunica la vida en relación con el misterio, acude a la capacidad simbólica, poética, narrativa, biográfica, ritual y celebrativa, ya que lo que se transmite es la experiencia de haber sido tocado profundamente por la divinidad, y la mejor forma que encontraron los místicos para comunicarla fue el lenguaje amoroso y alegórico.

\footnotetext{
${ }^{53}$ Bara Bancel, "Las raíces de la felicidad, según el Maestro Eckhart", 144.
} 
Ahora bien, no podemos olvidar que siempre estaremos situados ante el misterio, inabarcable, inefable; y tampoco desconocer que llevamos dentro la divinidad del Dios al que no podemos negar, porque para el cristiano Dios es el donador de la vida, el Padre que ha creado al ser humano y, por más que se quiera abandonar o renunciar a él, siempre estará ahí esperando, porque la condición de hijo nunca se pierde.

Le corresponde al hombre obligar a Dios a entrar en su vida y esto solo se logra mediante la aniquilación o el desasimiento, como decía el maestro Eckhart: "Se trata de una compensación equitativa y un negocio justo: en la medida en que sales de todas las cosas, en esa medida, ni más ni menos, entra Dios con todo lo suyo, siempre que salgas completamente de lo tuyo en todas las cosas"..$^{54}$

Actualmente, en América Latina, vivimos una época en la que se percibe un avivamiento de manifestaciones religiosas, un reconocimiento de espiritualidades, un deseo de oración y contemplación y una atención a la celebración del misterio. Vemos surgir prácticas religiosas y anhelos por tener experiencias místicas, en el sentido de que ocurran cosas extraordinarias en la vida de las personas, o en el sentido de respuestas a interrogantes por la vida o estados anímicos. Lo cierto es que todos queremos sentir y saber algo sobre el misterio, como dice Miguel De Certau:

...toda espiritualidad responde a los interrogantes de un tiempo, y nunca les responde de otra manera que en los mismos términos de tales interrogantes, porque son aquellos que viven y que hablan los hombres de una sociedad; tanto los cristianos como los otros. ${ }^{55}$

Desde la perspectiva del lenguaje de los místicos, se reconoce que ellos hacen un fuerte llamado a una vida despojada, como anota San Pablo: "El cual siendo de condición divina, no reivindicó su derecho a ser tratado igual a Dios, sino que se despojó de sí mismo. [...]. Se rebajó a sí mismo, haciéndose obediente hasta la muerte" (Flp 2,6-8).

Con esta obediencia de corte paulino los místicos han sabido conducir pedagógicamente al ser humano al encuentro con Dios. Ellos enseñaron una vía de conocimiento en la relación con Dios, esa vía es el desasimiento, anonadamiento, aniquilamiento o kénosis; enseñaron a relacionarse con Dios en lo cotidiano, con una actitud sencilla y básica ante la vida y ante el misterio. Con este tipo de relación, el ser humano reconoce su dependencia, pero a la vez descubre su libertad, esa libertad de quien solo tiene lo necesario para vivir sin apegos ni bienes que estorben, de quien solo tiene un corazón desasido y ocupado por Dios.

\footnotetext{
${ }^{54}$ Maestro Eckhart, Obras alemanas. Tratados y sermones, 342.

${ }^{55}$ De Certeau, La debilidad de creer, 51.
} 


\section{Bibliografía}

Anónimo inglés (siglo XIV). La nube del no saber y el libro de la orientación particular (5a. ed.). Madrid: Paulinas, 1998.

Areopagita, Pseudo Dionisio. La jerarquía celestial, la jerarquía eclesiástica, la teología mistica. Traducción de Pablo A. Cavallero. Buenos Aires: Losada, 2007.

. Obras completas. Madrid: Biblioteca de Autores Cristianos, 1995.

Bara Bancel, Silvia. "Las raíces de la felicidad, según el Maestro Eckhart". En Mística y filosofía, editado por F. Javier Sancho Fermín, 131-144. Ávila: CITes, 2008.

Barrett, Cryl. Ética y creencia religiosa en Wittgenstein. Madrid: Alianza, 1994.

De Amberes, Hadewijch. Flores de Flandes. Traducción del neerlandés medio-bajo por Carmen Ros y Loet Swart. Madrid: Biblioteca de Autores Cristianos, 2001. . Visiones. Traducción de María Tabuyo Ortega. Barcelona: Medievalla, 2005.

Beneito, Pablo; Lorenzo Piera y Juan José Barcenilla. Mujeres de luz. La mistica femenina y lo femenino en la mistica. Madrid: Trotta, 2001.

Concilio Vaticano II. Gaudium et spes. Madrid: Biblioteca de Autores Cristianos, 1976.

De Binguen, Hildegarda. Scivias. Conoce los caminos. Traducción de Antonio Castro Safra y Mónica Castro. Madrid, Trotta, 1999.

De Certeau, Michel. La debilidad de creer. Buenos Aires: Katz, 2006. . La fábula mistica. Epilogo de Carló Ossola. Madrid: Siruela, 2006.

De Paz Blanco, María Rosario. "Lenguaje y experiencia en la mística judía”. Tesis de Doctorado en Filosofía y Derecho, Universidad Complutense de Madrid, 2008.

Deseille, Placide y Enzo Bianchi. Pacomio, e la vita comunitaria. Comunità di Bose: Qiqajon, 1998.

Faggin, Giuseppe. Meister Eckharty la mistica alemana medieval. Traducción de Elena Sella. Buenos Aires: Sudamérica, 1953.

Flórez, Alfonso. La ética de Meister Eckhart. Bogotá: Pontificia Universidad Javeriana, 1983.

González, Edith. "Mística medieval femenina. El lenguaje teológico de ayer y de hoy". Tesis doctoral en Teología, Pontificia Universidad Javeriana, Bogotá, 2015.

Hass, Alois M. Visión en azul. Estudios de mistica europea. Traducción de Victoria Cirlot y Amador Vega. Madrid: Ediciones Siruela, 1999. 
Ladrière, Jean. La articulación de sentido. Salamanca: Sígueme, 2011.

Macquarrie, John. God-talk, el análisis del lenguaje y la lógica de la teología. Salamanca: Sígueme, 1976.

Maestro Eckhart. Obras alemanas. Tratados y sermones. Traducido por Ilse M. de Brugger. Barcelona: Edhasa, 1983.

Mañon, Guillermo. "La mística del Maestro Eckhart". Biblioteca ITAM, http:// biblioteca.itam.mx/estudios/60-89/74/GuillermoManonLamisticadelmaestro. pdf (consultado el 19 de enero de 2015).

Martín Velasco, Juan de Dios. "La experiencia de Dios hoy”. Maresa 75 (2003): 37-66.

Norwich, Juliana. Libro de visiones y revelaciones. Edición y traducción de María Tabuyo. Madrid: Trotta, 2002.

Porete, Margarita. El espejo de las almas simples. Edición y traducción de Blanca Gari. Madrid: Siruela, 2005.

Ruiz Bueno, Daniel (traducción e introducción). El pastor de Hermas. Madrid: Aspas, 1947.

San Agustín. De doctrina christiana. Traducido por R. P. H. Green. New York: Oxford University Press, 1995.

San Bernardo (Abad de Claraval). Sobre el cántico de los cánticos de Salomón. Traducido al español por el P. Mro. Fr. Adriano de Huerta. Valladolid: Tomás Cermeño, MDCCC.

Santa Ángela de Foligno. Experiencia de Dios amor. Traducción, introducción y notas de fray Contardo Miglioranza. Madrid: Apostolado Mariano. s/f.

Santa Teresa de Jesús. El libro de la vida. Madrid: Algaba, 2007. . Obras. Tomo I. Madrid: Mercurio, 1752

Schillebeeckx, Edward. En torno al problema de Jesús. Claves de una cristología. Madrid: Cristiandad, 1983.

Searle, John. Actos de habla. Madrid: Cátedra. 2004.

Tabuyo, María y Agustín López (traductores). Cábala. Nuevas perspectivas Madrid: Siruela, 2005.

Vide, Vicente. Los lenguajes de Dios. Pragmática, lingüistica y teología. Bilbao: Universidad Deusto, 1999.

Wittgenstein, Ludwig. Tractatus Logico-Philosophicus. Madrid: Tecnos, 2013. 